\title{
Unusual Shoulder Pain Etiology in Old Man: Synovial Chondromatosis
}

\author{
Yaşlı Bir Hastada Nadir Omuz Ağrısı Nedeni: Sinoviyal Kondromatozis
}

Fatih Bağcıer, Ayhan Kul, Akın Erdal

Atatürk University Faculty of Medicine, Department of Physical Medicine and Rehabilitation, Erzurum, Turkey

\section{To the Editor;}

A 82-year-old male patient presented to our clinic with progressively worsening left shoulder pain. The pain started about 6 months ago, increased over time, spreading to the chest region. The characteristic of the pain was mechanical He did not feel pain while sleeping. Previously, he had received analgesic medications but there was no significant improvement. There was no pain in any other joint, and there was no history of disease or trauma. Physical examination revealed the motion of the left shoulder joint was limited and painful in all directions. Neer's impingement sign, Hawkins-Kennedy test, Yergasons tests were positive. There were no neurological deficits of the upper extremities. Serological and biochemical markers were normal. Impingement syndrome was diagnosed with physical examination. Magnetic resonance imaging (MRI)

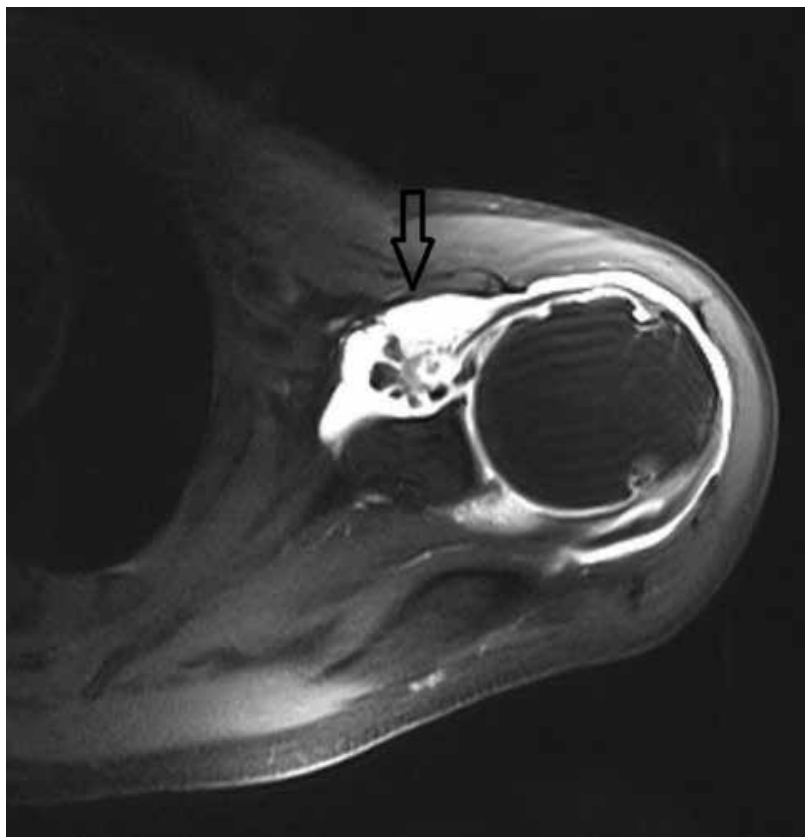

Figure 1. Synovial chondromatosis, which filled the subscapuler muscle region in axial section was seen of the left shoulder revealed findings consistent with synovial chondromatosis (SC), which filled the subscapuler muscle region (Figure 1). Orthopedic surgical procedures including arthroscopic debridement were planned with symptomatic left shoulder.

$\mathrm{SC}$ is a rare arthropathy of unknown etiology. The disease is generally monoarticular, usually occurs unilaterally in the large joints like the knee, hip, and elbow characterized by proliferation of the synovium with cartilaginous metaplasia (1). However any joint may be involved. Symptomatic presentation is quoted in the current literature mainly at the ages of 30 to 50 of a patient's life. The diagnosis of SC is given after a thorough history, physical examination, and radiographic examination. Chronic, progressive pain, swelling, loss of motion and locking are more commonly seen symptoms, and soft-tissue swelling, crepitation, palpable loose bodies, and limited range of motion are the most common physical signs. It is beneficial to carry out computed tomography and MRI scans to identify and localize the lesions, and they also help to differentiate between other differential diagnoses. As radiotherapy and chemotherapy have no effect on SC, surgical removal of the affected synovium and the loose bodies is the preferred treatment (2). In the literature Kose et al. (3) presented a case with unilateral hip joint synovial osteochondromatosis, Giannetti et al. (4) presented a case with unilateral elbow joint synovial osteochondromatosis, Shearer et al. (5) presented a case with bilateral ankle joint synovial osteochondromatosis. Synovial osteochondromatosis was present in our case uncommon shoulder pain etiology in old man.

Keywords: Synovial chondromatosis, shoulder joint, metaplastic disorder

Anahtar kelimeler: Sinoviyal kondromatozis, omuz eklemi, metaplastik hastalık

\section{Ethics}

Informed Consent: It was taken.

Peer-review: Internal peer-reviewed. 


\section{Authorship Contributions}

Concept: Fatih Bağcıer, Ayhan Kul, Design: Fatih Bağcıer, Ayhan

Kul, Data Collection or Processing: Fatih Bağcıer, Ayhan Kul, Analysis or Interpretation: Fatih Bağcıer, Ayhan Kul, Literature Search: Fatih Bağcıer, Ayhan Kul, Writing: Fatih Bağcıer, Ayhan Kul, Akın Erdal.

Conflict of Interest: No conflict of interest was declared by the authors.

Financial Disclosure: The authors declared that this study received no financial support.

\section{References}

1. Yu GV, Zema RL, Johnson RWS: Synovial chondromatosis. A case report and review of the literature. J Am Podiatr Med Assoc Journal 2002;92:247-54.

2. Shanbhag AC, Balakrishnan A, Bhaduri RKC. Primary synovial chondromatosis. J Indian Rheumatol Assoc 200;12:29-30.

3. Kose MM, Durmus O, Ayhan MY, Batmaz AG. A rare cause of chronic hip pain: Intraarticular synovial chondromatosis. Acta Reumatol Port 2014;39:349-50.

4. Giannetti S, Santucci A, Patricola A, Stancati A, Di Sanzo V. Neglected synovial osteochondromatosis of the elbow: A rare case. World J Surg Oncol 2013;11:233.

5. Shearer $H$, Stern $P$, Brubacher A, Pringle T. A case report of bilateral synovial chondromatosis of the ankle. Chiropr Osteopat 2007; 15:8. 